\title{
A "Catholic" Consistory? The Bipartisan Consistorial Court of Echallens in the Vaud (Sixteenth to Eighteenth Century)
}

\author{
Christian Grosse \\ Translated by Christine Rhone
}

With patience and perseverance in equal measure, Raymond Mentzer has, for several years, conducted research all across France to locate and meticulously describe the registers held by the Huguenot consistories from the Reformation to the Revocation of the Edict of Nantes. ${ }^{1}$ We know that the recording and preservation of the minutes of the consistories was not only a major tool in the exercise of Reformed ecclesiastical discipline, the instrument of its efficacy, but also a collective record and testimony before the divine of the constancy with which the Reformed Churches sought to guide the penitential progress of the faithful, between the fall into sin and the return to the way of amendment. ${ }^{2}$ The project, essential for stimulating students and researchers to produce new works on Reformed ecclesiastical discipline under the Ancien Régime in France, was ambitious and difficult to achieve, given the extreme dispersal of these registers in various collections of archives.

Raymond Mentzer has nevertheless managed to uncover and inventory 309 registers and to furnish the complete list to the scholarly community together with an important introduction and an extensive bibliography in his book: Les registres des Consistoires des églises réformées de France, XVIe-XVIIe siècles: un inventaire (Geneva: Droz, 2014). His work has directly inspired a similar undertaking that aims to create a directory, as complete as possible, of the registers left by the Reformed consistories of French-speaking Switzerland (Suisse Romande), from the Reformation to the end of the Ancien Régime. With his permission, this directory has adopted the format of the information files that Mentzer developed to describe each register, so that researchers can easily circulate between the inventories of France and French-speaking Switzerland. A team of five historians, specializing in the history of the Churches and

1 The present text was translated by Christine Rhone. I thank Amélie Isoz for her careful reading of the original text as well as her comments and corrections.

2 Mentzer, "La mémoire d'une fausse religion," 461-475; Grosse, "Rationalité graphique et discipline ecclésiastique”; and Grosse, "Inquisition and Consistory Records: Consistories."

(C) KONINKLIJKE BRILL NV, LEIDEN, 2018 | DOI 10.1163/9789004363410_004 
consistories of French-speaking Switzerland as well as the local archive collections, was formed to complete the project (Amélie Isoz, Salomon Rizzo, Michèle Robert, Nicole Staremberg, and myself). Our team was confronted with a situation different from that which Mentzer faced in France: in Frenchspeaking Switzerland, the corpus, covering three centuries, included a far greater number of preserved registers (more than 70o; less than half that number for France); on the other hand, locating them presented distinctly fewer difficulties since the majority of the documents is today deposited - with a few local exceptions-in cantonal archive collections. In France, in contrast, the registers are dispersed in national, departmental, municipal, or private archives, when they were not taken abroad in the baggage of the Huguenots leaving the kingdom after the Revocation of the Edict of Nantes. ${ }^{3}$

In the course of the enquiry, our team was surprised to discover in the inventory of the "Bda" collection of the Vaud cantonal archives, which assembles the consistory registers, an entry referring to a document identified as originating from a "Catholic" consistory; one can in fact read the following entry in this inventory: "Bda 50 ECHALLENS (CATHOLIC)." ${ }^{4}$ The following category in this same inventory is described in this way: "Bda ${ }_{51}$ ECHALLENS (REFORMED)." Keeping to the facts that this inventory indicates, the town of Echallens, situated in the heart of the Vaud, exactly between Lausanne and Yverdon-les-Bains, would thus have had two consistories in the early modern era, one Catholic and the other Reformed.

As surprising as it may seem, the idea that Echallens would have been in a completely original situation within the landscape of the Reformed consistories through the coexistence of two ecclesiastical tribunals both called "consistories" is not, in fact, new. One finds it explicitly expressed already in ${ }^{1772 \text {, }}$ in the article of the Encyclopédie of Yverdon written by Albrecht de Haller and concerning Echallens: "Echallens is really only a castellany. ... It has a consistory for the Reformed parishes. For the Catholics, there is a consistorial court of four assessors of the two religions, under the presidency of the bailiff, who nominates them; it decides in first instance concerning cases of matrimony and impurity." ${ }^{5}$ We observe furthermore that this particular case was rather well-known in the eighteenth century, since the information contained in the article by de Haller circulated rather widely: the article "Echallens" was reprinted in 1780 in the Dictionnaire universel des sciences morale, économique,

3 Mentzer, Les registres des Consistoires des églises réformées de France, 35-51.

4 Archives cantonales vaudoises (henceforth: ACv), Bda/96/Inv. 28: "SERIE Bda. REGISTRES DES CONSISTOIRES. 1574-1798)."

5 Encyclopédie ou dictionnaire universel raisonné des connoissances humaines, 55. 
politique et diplomatique, ou bibliothèque de l'homme-Etat et du citoyen by Jean-Baptiste Robinet, ${ }^{6}$ then, in 1788 , in the Dictionnaire historique, politique et géographique de la Suisse by Vincenz Bernhard von Tscharner and Gottlieb Emmanuel von Haller. ${ }^{7}$

A somewhat closer examination, such as the one conducted with a view to establishing the directory of the consistorial registers of French-speaking Switzerland, enables us, however, to clarify the question and understand the source of the confusion. It first makes apparent that the document, to which the shelf number Bda 50 refers, is not, properly speaking, a register. It is no more than a notebook of twelve pages, of which only three bear a consistorial statement, concerning two sessions held on 10 and 17 October 1740 . On the other hand, under the shelf number Bda $5^{1}$ one finds a more substantial set of documents since it includes two notebooks and three registers that cover, with a few lacunas, most of the eighteenth century (1721-1794). ${ }^{8}$ Bda 50 and $5^{1}$ do not really form two distinct series of documents, but bring together the corpus of the statements of one single consistory, that of Echallens, to which are added two collections of loose papers including sentences and correspondence, classified in another collection..$^{9}$ The item numbered Bda 50, in this corpus, is a single statement recorded for unknown reasons in an individual notebook, entered late and separately in the collections of the Vaud cantonal archives, ${ }^{10}$ and inserted between the statements of the Echallens consistory

6 London: associated booksellers, 1780, 20-21.

7 In Geneva: Barde, Manget \& Comp., \& in Paris: Buisson, 1788, 1:312.

8 AVC, Bda 51/1: Register of the Echallens Consistory. From 4 May 1714 (the first session dating from 9 April 1721) to 8 February 1727. Lacuna: 22 November 1721-28 January 1723; ACV, Bda 51/2: Register of Echallens Consistory. From 3 September 1727 to 13 January 1736 . Lacunas: 8 September 1727-2 May 1729; 22 April 1730-3 July 1732; 31 July 1733-20 October 1735; ACV, Bda 51/3: Register of Echallens Consistory. From $22 * 1738$ (the month is illegible, but a subsisting final " $\mathrm{t}$ " suggests that it must be the month of juillet or août, that is, July or August) to 2 October 1747; ACV, Bda 51/4: Register of Echallens Consistory. From 9 October 1747 to 25 November 1783 (the last session dating from 10 March). Lacunas: 6 November 1748-24 February 1750; 5 November 1763-4 March 1766; 23 December 1774-14 March 1776; 8 May 1779-8 January 1781; 20 May 1781-7 February 1783; ACV, Bda 51/5: Register of Echallens Consistory, From 4 March 1784 (the first session dating from 25 August) to 8 April 1794. Lacuna: 26 August 1784-9 January 1786. $\mathrm{ACV}, \mathrm{Be}$ 1/18: Consistorial matters or procedures and sentences concerning paternity. From 8 March 1743 to 25 August 1797; ACV, Be 1/19: Consistorial matters or procedures and sentences concerning paternity. From 30 July 1754 to 11 June 1684 .

10 Notebook Bda 50 bears on the back of the last folio a note indicating that it was "Brought to the A.C.v. on 25 April 1995 by Mr. Maurice Conne." 
sessions of 17 July 1740 and 2 August 1741 contained in the register with the shelf number Bda 51/3.

The classification adopted by the Vaud cantonal archives is a unique and coherent series. How, then, did the distinction between two entries, one "Reformed" and the other "Catholic," arise within it? The only indication of what could have led to establishing this distinction resides in the mention, among the list of consistory members present at the session of 17 October 1740, of "the priest of Sonney instead of the priest of Bottens." The participation of this priest in this session, however, was neither the sign of the existence of a "Catholic" consistory, nor even the trace of an extraordinary session for which the presence of a priest would have been deemed useful. On the contrary, it reveals the most interesting and original characteristic of this situation in context of the Reformed ecclesiastical tribunals - namely, the ordinary functioning of the Echallens consistory. The indication showing that priests took part in these sessions appeared not only in notebook Bda 5o, but at the heading of almost all the sessions of the Echallens consistory in the eighteenth century. Their absence was, on the contrary, the exception. Nor are we in the situation that Haller described, with the parallel functioning of two consistories. The very specific feature of this consistory was precisely its structure of a bipartisan court. ${ }^{11}$ The aim of the present text, therefore, is to shed light on this structure, as well as the history and function of this consistory.

The bipartisan structure of the consistory of the Echallens is, as far as I can verify, a unique situation in the whole history of reformed consistories. While Echallens may not hold a central place in the general history of reformed churches, the uniqueness of this structure, never before studied as such, clearly deserves a close analysis. However, if we look at this exceptional situation from the point of view of the history of confessional coexistence in early modern Europe, the bipartisan consistory of Echallens appears less odd. Recent historiography has increasingly distanced itself from the dominant paradigm of confessionalization which emphasizes confessional confrontations, instead examining local situations of cohabitation between catholic and protestant communities. This more recent work has revealed the very pragmatic procedures these communities often conceived and followed in order to keep the peace and preserve a precarious confessional balance. While there are now many studies on cohabitation within families, neighborhoods, or civil

11 The term bipartisan (mi-partie) is generally used to apply to civil courts rather than consistories. I have chosen to use this word in the case of Echallens consistory, however, because the bipartisan nature of the consistory is an extension of the same bipartisan nature of the local municipal and judicial institutions. 
institutions, collaboration within ecclesiastical institutions remains far less understood. ${ }^{12}$ This again makes the situation in Echallens very interesting.

The town of Echallens was part of a set of seigneuries (with Orbe, Grandson, Bottens and Montagny-le-Corboz) jointly administered by the cities of Bern and Fribourg. In the context of the Burgundian Wars (1474-1477), these territories were in a first phase (1476) conceded jointly to the confederated cantons and then (1484) attributed, against compensation granted to the other cantons, exclusively to Bern and to Fribourg, which grouped them at that point into two common bailliages (also called "mixed" or "mediate" bailliages): that of Orbe and Echallens and that of Grandson. Each of these bailliages was governed during five years by a bailiff named in turns by Bern and Fribourg, who exercised sovereignty on these territories by "alternative," according to the terminology then employed. The bailiff, issued from one of these two cities, had to report on its administration to the other city. The joint government of these territories was based on an arrangement that required, moreover, that any matters of dispute be subject to a "conference" bringing together — generally at Morat - the representatives of the two sovereign States. ${ }^{13}$ This system remained satisfactory until the time of the Reformation, when the confessional choices of the two sovereign cities - Bern having adopted the Reformation in 1528 - placed them in opposite camps on the religious plane. ${ }^{14}$ After the first War of Kappel (1529), in a context where Bern endeavored to make all the territories subject to its

12 Cameron, Greengrass, and Roberts, eds, The Adventure of Religious Pluralism; Christin, La paix de religion; Boisson and Krumenacker, eds, La coexistence confessionnelle à l'épreuve.; Dixon, Freist, and Greengrass, eds, Living with religious diversity; François, Protestants et catholiques en Allemagne; Grosse, “Tolérance ou coexistence?”; Hanlon, Confession and Community; Kaplan, Divided by Faith; Luria, Sacred Boundaries; Höfele, Laque, Ruge, and Schmidt, eds, Representing Religious Pluralization; Walsham, "Cultures of Coexistence."

13 For Echallens specifically, see: Jaquemard, "Le régime des deux Etats Souverains à Echallens."

14 The situation of confessional cohabitation within joint territories existed elsewhere in the Swiss Confederation; several of these examples have been the object of focused studies. See especially: Head, "Shared Lordship, Authority, and Administration"; id., "Religious Coexistence and Confessional Conflict in the Vier Dörfer. Practices of toleration in Eastern Switzerland, 1525-1615; id., "Fragmented Dominion, Fragmented Churches: The Institutionalization of the Landfrieden in the Thurgau, 1531-1610"; Stucki, "Protestants et Catholiques sur les mêmes bancs d'Eglises. Tolérance pratiquée en 1670?”; Volkland, "Konfessionelle Grenzen zwischen Auflösung und Verhärtung Bikonfessionelle Gemeinden in der Gemeinen Vogtei Thurgau ( $\mathrm{CH}$ ) des 17. Jahrhunderts"; id., "Reformiert sein 'unter' Katholiken. Zur religiösen Praxis reformiert Gläubiger in gemischtkonfessionellen Gemeinden der Alten Eidgenossenschaft im 17. Jahrhundert”; id., Konfession und 
authority accept the Reformation, while Fribourg attempted to maintain them in obedience to Rome, an agreement between the two cities took place, which adapted the measures of the first Peace of Kappel to the common bailliages. This agreement or "way of life" [ mode de vivre], concluded on 3o January 1532 and published successively in Orbe and in Grandson on the following 4 and 5 March, proscribed religious insults, provocations, and violence; required not only the forgiveness but also the active forgetting of past grievances; ${ }^{15}$ organized the simultaneum, that is to say the sharing, regulated in a detailed manner, of places of worship; ${ }^{16}$ and granted freedom of conscience to the subjects of these territories. In the version of this text published at Grandson appeared an additional article stipulating that where the Mass had been abolished by the majority of the parishioners, it would not be re-established, but where the majority voted in its favor, its maintenance or its suppression could be subject to a new vote by the parishioners; furthermore, where the majority opted for maintaining the Mass, Reformed preaching also had to be offered. ${ }^{17}$ This agreement, more favorable to the Reformation than to the Catholic Church, reflected the power relationship that then existed between Bern and Fribourg and that endured in the course of the following years. The solution of the "Plus", that is to say, the majority vote to decide on the confessional orientation of the parishes where it was taken, inspired by a procedure established as early as 1524 in Appenzell and extended to the common bailliages by the first Peace of Kappel (Treaty of Steinhausen), was confirmed in the course of subsequent negotiations between Bern and Fribourg conducted in 1538,

Selbstverständnis: reformierte Rituale in der gemischtkonfessionellen Kleinstadt Bischofszell im 17. Jahrhundert.

15 On the clauses regarding oubliance in religious peace, see: Grosse, "Imprescriptibilité ou pardon?".

16 The bibliography on the question of the simultaneum is rather extensive; see notably, recently: Christin, "Le temple disputé: les Réformes et l'espace liturgique au XVI ${ }^{\mathrm{e}}$ siècle"; Head, "Fragmented Dominion, Fragmented Churches"; Jalabert, "Le simultaneum en Lorraine orientale et en Alsace Bossue (1648-1789)"; Luria, "Sharing sacred space." The simultaneum at Echallens is nevertheless an extremely interesting case, in the sense that it is exceptionally well documented over the whole modern period, and that clashes and agreements are interspersed in the reports between Catholics and Reformed concerning the use of the temple and the cemetery throughout the course of the period.

17 Vuilleumier, Histoire de l'Eglise réformée du Pays de Vaud, vol. 1, 80-81; Herminjard, Correspondance des réformateurs, vol. 2, 401-404, nº 371; Junod, ed., Mémoires de Pierrefleur, $61-63$. 
then again in $1554 \cdot{ }^{18}$ It was then applied, as an instrument of religious conquest by Bern, with success until 1619 .

In the bailliage of Grandson, it was thus the entire group of parishes that progressively accepted the Reformation between 1531 and 1564 (1531: Fiez; 1533: Yvonnand; 1537: Concise, Onnens and Champagne; 1538: Giez; 1552: Provence; ${ }^{19}$ 1554: Montagny and Grandson; 1555: Saint-Maurice; 1564: Bonvillars). ${ }^{20}$ In the bailliage of Orbe-Echallens, the process unfolded in two phases, with a first wave of "Plus" that confirmed the acceptance of the Reformation between 1553 and 1575 (1553: Oulens; 1554: Orbe; 1570: Mex; 1575: Goumouëns-la-Ville) and a second wave that completed it in 1619, with the abolition of the Mass voted at Penthéréaz and at Poliez-le-Grand. ${ }^{21}$ Between the end of the sixteenth century and the beginning of the seventeenth, the resistance of Fribourg became more determined and the process of conversion by means of the "Plus" then reached its limits. The parishes of Assens, where aborted attempts to vote took place in 1602 and 1617, and Bottens and Echallens, where the Catholic majority excluded a majority decision in favor of the Reformation, thus maintained a situation of confessional coexistence throughout the Ancien Régime. ${ }^{22}$

Sheltering the castle where the bailiff was based, the town of Echallens was administered, at least from the beginning of the seventeenth century, according to a principle of parity between the Catholics and the Reformed. This principle not only determined the sharing — often difficult — of the same religious building, ${ }^{23}$ but also governed the functioning of institutions. The Council that directed the town was thus composed of an equal number of Protestant and Catholic members and the judicial system counted as many representatives of one religion as the other. The Rights and Freedoms of Echallens [franchises], approved by Bern and Fribourg in 1715, thus provided that the city exercising alternative sovereignty would elect for certain responsibilities "de quatre sujets de l'une et de l'autre des religions" [four subjects of one religion and of the

18 Dupraz, Introduction de la Réforme par le "Plus", 1-12. On the question of the introduction of majority voting in the procedures of Swiss decision-making, see Elsener, "Zur Geschichte des Majoritätsprinzips," and more generally on voting, Christin, Vox populi (and specifically pp. 140-16o for the "Plus" in the Vaud).

19 See specifically for Provence: Meylan, Le village de Provence et la Réformation.

20 Dupraz, Introduction de la Réforme par le "Plus", 12-14.

21 Ibid., 15-41, 83-113; for Goumoëns, see specifically: Blakeley, James J., "Did the Pastor Buy You a Drink?': Religious Choice, Clerical Persuasion, and Confessional Elections in the Village of Goumoëns." In Sixteenth Century Journal, 44 (2013), 345-366.

22 Dupraz, Introduction de la Réforme par le "Plus", 97-112, 146-190.

23 Grandjean, Les temples vaudois, 307. 
other $] \cdot{ }^{24}$ Rather strictly applied, the principle extended as far as the procedure of admission to the bourgeoisie: the reception of a Catholic could only be followed by the reception of a Reformed so as to maintain balance of the power relationships. ${ }^{25}$

This principle also applied to the consistorial court, starting from a period that is, however, difficult to define. Concerning the date of institution of the Echallens consistory, the available information is actually too fragmentary to form an exact and definitive idea. It is known that the Bernese mandate ordering the bailiffs to establish consistories in all the parishes of the Vaud that had accepted the Reformation dated from 27 May 1558. Lacking systematic application, it was reiterated on two occasions in August of the same year and in February $1559 .{ }^{26}$ According to Henri Vuilleumier, historian of the Reformation in the Vaud, the establishment of the consistories of the common bailliage of Orbe and Echallens would in fact have dated from this period. Based on Histoire de la Réformation de la Suisse (1727-1728) by Abraham Ruchat and on the Actes de la Classe d'Orbe, of which the pastors of Echallens were part, he stated firstly that towards 1559, the Bernese government "institua aussi pour les réformés de [ la châtellenie d'Echallens] un consistoire, comme il en avait déjà institué en 1553 pour les ressortissants de la châtellenie d'Orbe, à Grandson et à Morat pour ceux de ces deux bailliages" [also instituted a consistory for the Reformed of (the castellany of Echallens), as one had already been instituted in 1553 for the citizens of the castellany of Orbe, at Grandson and at Morat for those of these two bailliages $].{ }^{27}$ Secondly, he indicated more generally that "dès les temps de la Réformation, un consistoire avait été établi dans chacune des deux châtellenies, à Orbe d'abord puis à Echallens" [as early as the time of the Reformation, a consistory had been established in each of the two castellanies, first at Orbe, then at Echallens $].^{28}$ It is true that in the case of Orbe, we know of a decision of the sovereign cities, dating from 1558 and explicitly concerning the creation of a consistory: this decision also implied that the jurisdiction of this consistory,

24 Matzinger-Pfister, Les Coutumiers du Pays de Vaud à l'époque bernoise, 1536-1798, 457.

25 Matzinger, "L'introduction de la Réforme dans les bailliages communs de Berne et Fribourg: son évolution à Echallens," 40 and "Echallens, centre administratif et judiciaire," 57; Ebener, Le régime des deux Etats souverains et les aléas de la coexistence confessionnelle, 49-50.

26 Matzinger-Pfister, "Lintroduction des consistoires dans le pays de Vaud," 117-118; id. "L'organisation politique, judiciaire et administrative des bailliages vaudois sous l'Ancien Régime (1536-1798)," 61-64.

27 Vuilleumier, Histoire de l'Eglise réformée du Pays de Vaud, 1:586.

28 Vuilleumier, Histoire de l'Eglise réformée du Pays de Vaud, 1:275. 
meeting at Orbe, extended both to Grandson and to Echallens. ${ }^{29}$ Between this decision and the early eighteenth century, however, a consistorial authority began to meet at Echallens independently of the Orbe consistory.

The preserved registers of Echallens consistory enable us to establish that, in any case, this authority existed on 9 April 1721, date of the first statement. But on the back cover of the first volume, we read the transcription of a decision concerning the functioning of the consistory taken "in the assembly of 16 November 1713." Furthermore, a loose paper inserted in the first of these registers and probably comprising part of its cover suggests an existence earlier than the date of the first statement, since it bears the following indication: "Suitte du Registre des assemblées Consistoriales qui se convoquent à Eschâlens" [Continuation of the Register of the Consistorial assemblies that meet at Eschâlens]. ${ }^{30}$ Without convincing evidence for the sixteenth and seventeenth centuries, these elements thus lead to the conclusion that the Echallens consistory existed at the latest starting in 1713 .

If it is therefore difficult to establish when exactly a consistory started to function at Echallens itself, we nevertheless have several decisions that to a certain extent regulated the exercise of discipline among the whole group of the common bailliages and that had an impact on the way in which the Echallens consistory actually worked in the eighteenth century, that is to say, starting from the time when its registers are preserved. From 1554, Bern and Fribourg jointly promulgated a ruling entitled: "accord et convention concernant le Consistoire, les excez d'yvrognerie, la punition des vices manifestes, et de l'adultere et paillardise. Item pour le Divorce et pretentions en faict de Mariage, ès Bailliages communs de Morat, Grandson, et Eschallens" [agreement and convention concerning the Consistory, excesses of drunkenness, the punishment of manifest vices, adultery and pailliardise (sexual immorality); also for Divorce and claims concerning Marriage, of the common Bailliages of Morat, Grandson, and Echallens]. It is, in all plausibility, to this document that the first preserved register of Echallens consistory referred when it indicated that its sessions "se convoquent à Eschâlens, à la maniere qu'il est prescrit par le Concordat conclud entre les deux Tres Illustres Souverains de ces lieux" [assemble at Echallens,

29 "Auf dem Bericht, dass die Prädicanten der Herrschaft Orbach und Echallens, sowie die von Grandson, um einen gelegenen Ort für Abhaltung ihres Chorgerichts ansuchen und dass dieses nöthig sei, indem einige Reformierte anderswohin zur Kirche gehen und einige Katholische an verbotenen Tage Fleisch essen, wird das Consistorium oder Chorgericht beider Herrschaften nach Orbach verlegt." (Die Eidgenössischen Abschiede, 1350 (1558).)

$30 \quad$ ACV, Bda 51/1 (loose sheet). 
in the manner prescribed by the Concordat concluded between the two Very Illustrious Sovereigns of these places]. ${ }^{31}$

In this ruling, Bern and Fribourg agreed on a distribution of roles between the different authorities who were responsible for regulating social mores. Drunkenness, gambling, excesses of dress and other moral offenses of this order were sanctioned by a fine inflicted by the bailiff, of which the product was then distributed equally between the two sovereign States. In cases of adultery and illicit sexual relations ("fornication") that did not lead to divorce, it provided that the bailiff should form an ad hoc court "de quatre ou six Prud'hummes" [of four or six wise men] that would lead an investigation in the light of which it would pronounce a sentence. Finally, purely matrimonial matters, requests for divorce or disputes concerning engagements to marry, were directly referred to one of the cities exercising sovereignty on the common bailliage. ${ }^{32}$ This ruling was reproduced in the general collections of consistorial laws published in 1640 and in $1746 .^{33}$ It thus remained in force throughout the Ancien Régime.

Two texts completing these measures were added in 1757-1758. The Bernese authorities published, firstly, in 1758, Loix consistoriales pour les trois baillages mediats, Morat, Grandson, et Echallens, of which a German version had appeared the preceding year. ${ }^{34}$ This was a republication of articles that already featured in the general collection of the Loix consistoriales published in 1746, with the difference that the version of $1757-175^{8}$ was expunged of references to the Supreme Consistory of Bern. ${ }^{35}$ The text adapted the functioning of the consistories of the Vaud to the particular situation of the common bailliages by providing that all matters ordinarily under the jurisdiction of the Bernese

$3_{1}$ ACV, Bda 51/1 (loose sheet). In 1640, this ruling was referred to as an "accord et convention" [agreement and convention] and in 1746 as a "Convenant fait entre les deux Etats de Berne de Frybourg" [Covenant made between the two States of Bern and Fribourg] (see above note 85 ).

32 Die Eidgenössischen Abschiede, 889.

33 Loix, et ordonnances du Consistoire de la ville de Berne, tant pour causes matrimoniales, que chastiments d'Adultere, Paillardise et autres vices et transgressions, Comme icelles ont esté premierement faites, et en apres par diverses fois changées, selon les occurences, qui se sont presentées; Et maintenant de nouveau corrigées, augmentées, et esclaircies, pour cy apres estre observées tant en la Ville, que au Pays, Berne: Estienne Fabry, 1640, 72-73; Loix consitoriales de la ville et republique de Berne, Berne: Imprimerie de Leurs Excellences, 1746, 114-115.

34 Chorgricht-Satzung für die drey gemeine Aemter Murten Grandson und Tscherlitz, Bern: in Hoch-Oberkeitlicher Druckerey, 1757; Loix consistoriales pour les trois baillages mediats, Morat, Grandson, et Echallens, Berne: Imprimerie de LL.EE., $175^{8 .}$

Vuilleumier, Histoire de l'Eglise réformée du Pays de Vaud, 4:30-31. 
government (Senate) or the Supreme Consistory of Bern were, in these common bailliages, under that of the "Alternative Sovereign," that is, the Council of Bern or the Council of Fribourg; in other words, every time that the Supreme Consistory of Bern, final authority of disciplinary procedure of the Vaud, was mentioned in the text of 1746 , it was replaced by "Alternative Sovereign," in that of 1758 . Much more extensive than the measures of 1554 , this text especially emphasized the fact that divorce procedures - the latter being permitted in cases that the Bernese consistorial laws endeavored to define narrowly and precisely - could finish before the Fribourg government which, however, being Catholic, recognized only the annulment of marriage and not divorce. ${ }^{36}$

The Bernese authorities published a second text in $175^{8}$ entitled: "Ordonnances qui doivent server de règle aux Pasteurs et aux Consistoires pour le maintien de la discipline ecclésiastique des Eglises réformées des trois Baillages Médiats de Morat, Grandson et Echallans" [Orders that the Pastors and the Consistories must use as a rule to maintain the ecclesiastical discipline of the Reformed churches of the three Common Bailliages of Morat, Grandson and Echallens]. ${ }^{37}$ This brochure of about ten pages picked up the fourth part of the Loix consistoriales of 1746, adding an article taken from the fifth part of the same document. It thus summarized a set of standards that concerned "attendance at public worship, resting on Sundays, catechism, baptism, Holy Communion and the religious examination of adults"; the supplementary article aimed specifically at banning ceremonies of the Roman church. ${ }^{38}$ For each of these questions, the text indicated the jurisdictions of surveillance and sanction that belonged respectively to the pastors, to the consistory and to its members, as well as to the bailiff.

Although the measures that we have just analyzed always appeared as applicable to all the common bailliages, their implementation also depended on local circumstances. If Grandson and Orbe, since the time of the "Plus", were entirely Reformed communities where these measures could therefore be applied without obstacle, the same was not true at Echallens, where Catholics and Protestants, priests and pastors coexisted. The examination of the registers of the Echallens consistory allows us to observe how this legal framework translated into practice and reveals working elements that it did not regulate.

${ }_{3} 6$ The precise analysis of the application of divorce procedures during the period when Fribourg exercised the alternative would merit a separate study; it is beyond the scope of the present introduction to the Echallens consistory.

37 Bern, Imprimerie de LL. EE., $175^{8}$.

38 Vuilleumier, Histoire de l'Eglise réformée du Pays de Vaud, 4:31. 
This examination thus reveals, first of all, that this authority, which referred to itself in its own statements as "venerable Consistory," "consistorial assembly," or again "consistorial court," was based in fact on a bipartisan organization, although this form of structure was not mentioned in any of the legal texts that we have just reviewed. Presided over by the bailiff himself or, in his absence, by his representative lieutenant baillival acting in his name (as was also the case for example in the Lausanne consistory ${ }^{39}$ ), the Echallens consistory generally brought together both the town priest and the minister. ${ }^{40}$ Often, the ministers and priests of the neighboring parishes of Assens, Bottens, and Polliez-le-Grand were also present. In the list of those present who appeared regularly at the beginning of the statement, the clerics were either mentioned one after the other with their respective function ("priest," "vicar," "minister," or "pastor"), or given a more general attribution that emphasized the bi-confessional character of the assembly since reference was made there to "Messieurs les Ecclésiastiques et Pasteurs des deux Religions" [Sirs the Clerics and Pastors of the two Religions] or "de l'une et de l'autre Religion" [of one and the other Religion]. This character furthermore extended to the assessors, that is, to the lay members of the ecclesiastical court, generally members of families of local notables in the case of the Vaud consistories, who were further described as being "moitié d'une religion, moitié d'une autre" [half of one religion, half of another]. ${ }^{41}$ This diversity was recognized by the vocabulary used by its contemporaries, the members of the ecclesiastical tribunal referring to it themselves as a "Consistoire myparti" [bipartisan Consistory]. ${ }^{42}$ It is in fact the most remarkable feature of the Echallens consistory since this bipartisan organization, relatively frequent at the level of municipal institutions in situations of confessional coexistence, ${ }^{43}$ never, to my knowledge, appears elsewhere in reference to consistorial institutions.

Although the joint participation of ministers and priests at the consistorial sessions thus comprised the most frequent situation, it nevertheless also happened that the consistory met in the absence of any cleric, ${ }^{44}$ or even-but

39 Staremberg Goy, "Contenir la parole et le geste à Lausanne au XVIII ${ }^{\mathrm{e}}$ siècle," 179.

40 On the priests of this bailliage and their level of education, see: Coutaz, "Les bibliothèques des curés d'Asens, de Bottens et d'Echallens."

$41 \mathrm{ACV}, \mathrm{Be} 1 / 2$ (bailliage tabs), f. $458 \mathrm{v}$ (document without a date but later than 1707).

$42 \mathrm{ACV}, \mathrm{Be} 1 / 2$ (bailliage tabs), f. 458v (document without a date but later than 1707).

43 On this question, see notably Christin, La paix de religion, 73-102; Head, "Shared Lordship, Authority, and Administration"; id. "Religious Coexistence and Confessional Conflict in the Vier Dörfer"; Kaplan, Divided by Faith, 223-230.

44 See for example ACV, Bda 51/2 (15 March 1730, 4 September 1732, 30 July 1733) (no pagination). This scenario also occurs in other consistories of the Vaud. 
more exceptionally - in the sole presence of a priest. ${ }^{45}$ In certain extremely rare cases the Echallens consistory thus appeared to have deserved the name that an entry in the classification of the Vaud cantonal archives had incorrectly given it!

The Echallens consistory did not meet on a regular basis. For example, between 1748 and 1768, it held on average only four or five sessions per year, knowing that in some years $(1749,1764,1765)$, it held none at all. On this level, its functioning did not fulfill the general requirements of the Bernese authorities concerning ecclesiastical courts: the latter were in fact normally supposed to meet every fifteen days ${ }^{46}$ and proceeded to general censures before the four annual celebrations of Holy Communion, ${ }^{47}$ which was never the case at Echallens. In fact this functioning more directly fulfilled one of the articles of the rules formulated by Bern and Fribourg in 1554, which mandated the bailiff to convene a session when a matter arose. This article targeted cases of adultery and paillardise. Now it was indeed this category that mobilized the Echallens consistory most frequently.

The concentration of consistorial activity on questions of illicit sexuality and matrimonial dispute was a phenomenon widely observed in Frenchspeaking Switzerland in the eighteenth century. ${ }^{48}$ In this regard, the character of the Echallens consistory was not unusual. But in its case, the general profile of the contentions that it addressed probably corresponded to a specific distribution of repressive functions. It was very probably the reflection of the ruling of 1554 . The latter entrusted, let us remember, the treatment of extra-marital and illicit sexuality ("adultery and fornication") to ad hoc sessions convened by the bailiff, directly turning over to the latter the repression of other moral offenses. However, this same ruling stipulated that matrimonial causes must be referred to the Council of the city exercising the "alternative." The registers of the Echallens consistory showed on this point that, in practice, a more subtle distribution of tasks took place. Even if illegitimate pregnancies formed the vast majority of the matters that it treated and even if the repression of illicit

45 See for example ACV, Bda 51/2 (8 May 1729; 5 September 1732) (no pagination).

46 Hubler, "Le fonctionnement du consistoire paroissial de Vallorbe au XVIII ${ }^{\mathrm{e}}$ siècle," 128.

47 Matzinger-Pfister, Les sources du droit du canton de Vaud, 209, nº 69 (Mandements et ordonnances chrétiennes, Bern, 25 May 1598).

48 Watt, The Making of Modern Marriage; Colombo, "Les femmes hors-la-loi consistoriale à Lausanne au XVIII ${ }^{\mathrm{e}}$ siècle"; Sirois, "Le Consistoire de Payerne au XVIII ${ }^{\mathrm{e}}$ siècle"; MottuWeber, “Paillardises,' ‘anticipation' et mariage de réparation à Genève au XVII ${ }^{\mathrm{e}}$ siecle”; Staremberg Goy, Nicole. “'Absolument contraire aux égards d'heus au sexe féminin'?”; Antoine, "Consistoire, Conseil des XXIV et police des mœurs au XVIII ${ }^{\mathrm{e}}$ siècle"; Delacroix, "Que donc ce que Dieu a joint, l'homme ne le sépare point." 
sexuality and its consequences claimed most of its attention, a set of matrimonial procedures composed above all of requests for divorce and disputes about engagements to marry appeared in the registers. The Echallens consistory thus assumed, in fact, a jurisdiction of investigation in these matters that the 1554 ruling did not attribute to it. In every case, however, the procedure was ultimately referred for a final decision to the "alternative" sovereign and never to the Supreme Consistory of Bern. From this viewpoint, the Echallens consistory conformed to the measures constituting its specific legal framework.

The fact that no offense of a religious type emerged from the statements of the Echallens consistory may be the result of the 1554 ruling, but we cannot dismiss the hypothesis that it may have been due to the overall evolution of the disciplinary activity of the Reformed ecclesiastical tribunals, which saw this category diminish everywhere in the eighteenth century. Similarly, moral offenses were scarcely mentioned in the registers. When they were mentioned, they were always closely connected with the central jurisdictions of this consistory: if the "vie déreglée" [lawless life] of François Marc Mayet was denounced, it was in relation to a matter of paillardise ${ }^{49}$ similarly, when the consistory accused two brothers of leading "une vie peu regleé et scandaleuse par leurs juremens et querelles domestiques" [a lawless and scandalous life by their swearing and domestic quarrelling], it was in context of the responsibility mandated to the ecclesiastical court to attend to the pacification of conflicts within the married couple and thus to preserve the stability of the matrimonial bond. ${ }^{50}$ Everything in the registers of the Echallens consistory seemed to confirm that the measures of the 1554 ruling, which attributed moral suppression not to the consistory but to the bailiff, were respected. For example, drunkenness, while still frequently suppressed by the other consistories of the Vaud, ${ }^{51}$ was never mentioned here. We will see, however, that the ministers and priests exercising ecclesiastical discipline were far from considering this matter unimportant.

The Echallens consistory thus essentially functioned as a matrimonial court - to which either the authorities or the concerned parties could referand as an investigative body regarding illegitimate pregnancies. It pronounced but few sanctions. Most of the procedures initiated within it finished at Bern and Fribourg where the final decisions were taken and the possible sanctions pronounced. But it happened in exceptional cases that it issued admonitions

49 ACV, Bda 51/2, 14 July $173^{2}$ (no pagination).

$50 \quad$ ACV, Bda $51 / 4,15$ March 1751 (no pagination).

51 The repression of excesses linked to the consumption of wine thus constituted " $5.6 \%$ of all the offenses brought to the attention of the Lausanne Consistory" between 1754 and 1793. (Staremberg Goy, Du buveur à l'ivrogne, 51.) 
and imposed penance by requiring that a believer "demander genoux ployés pardon à Dieu, à la chambre, et à tous ceux qu'il a scandalisé par sa faute" [kneeling, ask forgiveness of God, the court, and all those that he has scandalized by his fault $]{ }^{52}$ By proceeding in this way, the Echallens consistory went beyond the jurisdictions that the texts granted it and that directly guided its activity, but acted in conformity with the practice of the other contemporary consistories of the Vaud. ${ }^{53}$

Most of the individuals affected by its operations were Reformed. This observation, however, does not imply that it had no jurisdiction over the Catholic parishioners of Echallens. A procedure was even developed in 1714 to manage the order of the speakers in the consistory according to whether the matter treated concerned a Catholic or a Reformed party: "Il a été convenu entre messieurs les Ecclésiastiques de l'une et de l'autre des Religions, qu'en conséquence de ce qui se proposa, dans l'assemblée du $16^{e}$ novembre 1713, pour sçavoir quel devroit opiner le premier dans les assemblées ou ils sont obligés de se rencontrer ensemble, Que lorsqu'il s'agira des faits d'un Catholique, Messieurs les Curés opineront les premiers, mais lorsqu'il s'agira de ceux d'une personne de la Religion, ce sera Messieurs les Ministres." [It has been agreed among sirs the Clerics of both religions, that as a result of what was proposed in the assembly of 16 November 1713 , to know who should express an opinion first in the assemblies where they must meet, That when it will concern the facts of a Catholic, the priests will express their opinion first, but when it will be those of a Reformed, it will be the ministers. $]^{54}$ In fact, one observes that the Catholic believers were indeed summoned before the consistory for the same type of matters as those concerning the majority of their Reformed contemporaries: principally illegitimate pregnancies. ${ }^{55}$ If these cases were not absolutely exceptional, they remained nevertheless much rarer than those of the Reformed citizens summoned before the Echallens consistory.

This situation was, in practice, among the points of friction between the two communities. The Reformed thus complained about the fact that the Catholics "finissent entre eux sourdement" [agree tacitly among themselves] on all

52 ACV, Bda 51/2, 28 October 1727 (no pagination).

53 On penance and kneeling, see Grosse, “La 'pénitence publique’ réformée," et id., "Y a-t-il une raison réformée des gestes de piété?"

$54 \mathrm{AVC}, \mathrm{Bda} 51 / 2$, "Extrait d'une ordonnance, et convenu rapporté au precedent Registre à la datte du 4e may 1714" (no pagination; back cover).

55 AVC, Bda 51/2, 3 September 1727 (no pagination); AVC, Bda 51/4, 7 June 1774 (no pagination); ACV, Be 1/18 (bailliage tabs), 12 March 1771, 27 July 1773, 7 January 1774, 7 June 1774, 21 May 1783 (no pagination). 
the matters "ou les évoquent à Frybourg, quelle alternative qu'il ait" [or speak of them at Fribourg, whatever the alternative may be], while "on fait passer ... toutes celles des Reformés devant les Chambres miparties" [those of the Reformed are all sent before the bipartisan courts] and that they are "portées ensuitte autant à Fribourg, qu'à Berne, selon l'alternative" [then brought either to Fribourg or to Bern, according to the alternative]. ${ }^{56}$ On the other side, the priest of Bottens addressed complaints to the sovereign cities because "l'on a fait comparoitre un Cath[olique] $R$ [omain] pour fait d'adulteres dans un Consistoire mypartie, dont le Seigneur Bally etoit juge" [a R(oman) Cath(olic) has been made to appear before a bipartisan consistory for the fact of adulteries, where Lord Bally was judge], thus eliciting the response of a minister who reminded him that "les Cath[oliques] R[omains] doivent dépendre de ces Consistoires [mi-parties] comme les Réformés" [the $\mathrm{R}$ (oman) Cath(olics) must depend on these (bipartisan) consistories as do the Reformed]. ${ }^{57}$ If it was therefore contemplated at one time to arrange that "les affaires des Religionnaires se decidassent souverainement à Berne, et celles des Papistes à Fribourg, surtout en fait de marriage" [matters concerning the Reformed should be supremely decided in Bern, and those of the Papists in Fribourg, especially in facts of marriage],58 the consistorial registers showed that the Catholics never ceased, throughout the eighteenth century, to be summoned before the Echallens consistory, although always in fewer numbers than the Reformed.

In total, the Echallens consistory did not appear as an institution divided into two parts, one Catholic and the other Reformed, as the entries of the classification of the registers in the archives of Vaud Canton might lead us to believe. On the contrary, it constituted an area of collaboration between the Catholic and the Reformed churches, and, more precisely, between the clerics of the two confessions. Despite the episodes of tensions like the one previously mentioned, cooperation was a very real fact. The simultaneous presence of representatives of the two Churches within the consistory is attested over the whole of the eighteenth century. The statements established by the secretary of the consistory never registered any divergent views. Whatever confrontations may have arisen according to the periods outside the institution,

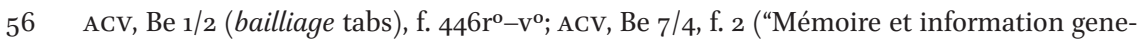
rales des Reformés, touchant les innovations introduties par les Catholiques Romains et autres choses de cette nature," no date). ACV, Be $1 / 2$ (bailliage tabs), f. $458 \mathrm{v}^{\circ}$ ("Memoire touchant les affaires des Eglises d'Echallens, Assens et Polliez le Grand," no date).

$5^{8}$ ACV, Be 1/2 (bailliage tabs), f. 463 ("Articles de Representations, touchant les Balliages d'Eschallens," no date). 
they had no repercussions on its ordinary activity. This collaboration, moreover, is verifiable elsewhere not only negatively - that is to say, by the absence of conflicts - but also positively, by the priests' regular contribution to the consistorial procedures. Thus, some of the matters were brought to the attention of the consistory on their initiative; ${ }^{59}$ in other cases, the priests provided the information permitting the principal actors and their supposed responsibilities to be identified. ${ }^{60}$ This common work even produced the particular situation in which the son of a pastor found himself before the consistory where a priest had the authority to rule on a matter concerning an engagement to marry. ${ }^{61}$

Sometimes, this collaboration extended even outside the consistory and the procedures that it treated. Several steps were thus jointly initiated by the ministers and priests of Echallens with the sovereign cities to raise the same problems relative to discipline. In June 1706, they thus addressed their sovereign to recall that "les Ecclesiastiques de l'une et de l'autre Religion dans vostre Balliage commun d'Eschallens, ont agit de concert pour detruire plusieurs abus et profanes coustumes qu'ils ont icy en usage" [the clerics of both religions in your common bailliage of Echallens have acted together to destroy several abuses and profane customs that are practiced here] and they regretted the fact that their efforts had not been relayed. In 1715, they denounced an entire series of abuses, including the failure to respect Sunday rest, gambling and dancing, as well as the excessive tolerance enjoyed by cabaret owners who defied the margin of maneuver created by the common government of the bailliage. Only after having insisted on several occasions did they obtain the publication of an edict repressing these violations and recalling the faithful to their religious duties on Sunday. ${ }^{62}$

Several factors allow us to explain the good collaboration observable in the work of the consistory. It is necessary first of all to remember that the concentration of its activity on the repression of illegitimate pregnancy placed at the heart of this work a question on which differences of doctrine had very little effect and that, on the contrary, had consensus within the elites that the

59 ACV, Bda 51/2, 8 May 1729 (no pagination); ACV, Bda 51/4, 27 July 1773, 28 June 1774 (no pagination); ACV, Be 1/18, 12 March 1771, 27 July 1773, 7 January 1774, 7 June 1774, 21 May 1783 (no pagination).

6o ACV, Bda 51/2, 8 May 1729 (no pagination); ACV, Be 1/18, 7 June 1774, 21 May 1783 (no pagination).

61 ACV, Bda 51/2, 21 April 1730 (no pagination).

62 ACV, Be $1 / 2$ (bailliage tabs), f. $496 \mathrm{r}^{\circ}-506 \mathrm{v}^{\mathrm{o}}$; Dupraz, Introduction de la Réforme par le "Plus", 172-176; the steps taken by the priests and ministers are reiterated in 1729 and in 1754 (Jaquemard, "Le régime des deux Etats Souverains à Echallens," 283-285; ACV, Be 1/6, $633-637)$. 
ministers and priests represented. All shared as well the concern to prevent the birth of bastard children, whose maintenance risked straining the local charitable structures. All also shared, in some cases, a social and cultural distance from a certain number of the defendants in matters of illegitimate pregnancy: faced with the latter, they were more united by moral reprobation and the feeling of social distinction than divided by confessional differences.

The consistory registers of Echallens thus demonstrate one of the key characteristics of situations involving confessional cohabitation, which historians have attempted to label with expressions like "religious coexistence," "everyday ecumenism," "tolerance of practical rationality," "interconfessional conviviality,"63 or even "mutual interaction and integration of competing confessional groups." 64 In a context in which intolerance was often considered a positive value, ${ }^{65}$ early modern contemporaries often demonstrated some degree of pragmatism. Preferring to maintain societal peace or communal unity in the face of external authorities, whether civic or ecclesiastical, they set aside, often only temporarily, the imperatives of confessional loyalty. Clearly this historical approach challenges the image developed by proponents of confessionalization, who have depicted a polarized society divided into rival communities. At the same time, however, historians who emphasize confessional cohabitation risk idealizing the concrete practices of confessional interactions. What consistory registers of Echallens show, instead, is the social actors' consideration of their multiple constraints and priorities, rather than any sort of practice of tolerance. Pastors and priests agreed on things within the limited context of the consistory because in that specific setting, their interests converged. But that did not prevent them, in other contexts, from working to defend their own confessional community. In light of the particular situation in Echallens, one could go so far as to assert-alongside other historians ${ }^{66}$ - that confessional collaboration and confrontation must be considered simultaneously: it is precisely because the confessional communities were in a strong enough position to defend themselves from rivals and maintain their own identities that they were also able to set the defense of that identity aside when other interests prevailed.

It is important to recognize, though, that the registers of Echallens consistory that are preserved relate to a period of progressive appeasement of

\footnotetext{
63 Walsham, "Cultures of Coexistence," 123.

64 Hanlon, Confession and community, 1.

65 Walsham, Charitable hatred.

66 Kaplan, Divided by Faith, 218; Spohnholz, Tactics of Toleration, 218-220; Walsham, "Cultures of Coexistence," 126.
} 
confessional conflicts and polemics. Even if the first quarter of the eighteenth century saw a regular resurgence of times of confrontation that still focused on the common use of the temple and the cemetery or on the division of church revenues and the costs of maintaining temples and wayside crosses, these struggles were then all the more easily regulated as a single will for appeasement motivated the sovereign cities. While the confessional tensions in Toggenburg resulted in the Second War of Villmergen (1712), Bern and Fribourg appeared more inclined to pacify conflicts in the specific context of their common bailliage of Orbe and Echallens. Several agreements were thus successively concluded: as early as 1702 , a concordat prohibited any innovation in religious matters in order to preclude any subjects of conflict; 67 in 1715 , Bern and Fribourg approved the customary law of Echallens; ${ }^{68}$ the one coming into effect in 1725 imposed the obligation to end all conflicts amicably and effectively managed to create the basis of a period of respite that is borne out for the remainder of the eighteenth century. ${ }^{69}$ In this context of appeasement, what is perceived as dangerous is less the confessional adversary than the secularization of minds and the progressively growing discredit of the Churches and of their representatives that secularization manifested. Among the common steps that the priests and ministers of the bailliage of Orbe and Echallens undertook thus appears the claim that "les Pasteurs [i.e.: curés et ministres] ne soyent pas méprisés dans la fonction de leurs charges, and que leur justes remonstrances ne soyent pas suivies du despect de ceux des dereglés de leurs troupeaux à qui elles sont addressees, comme" [the Pastors (i.e. priests and ministers) not be despised in the function of their duties, and that their just reproofs not be followed by disrespect from the lawless members of their flocks to which they are addressed, as], adds the text of this denunciation in a revelatory manner, "l'on en auroit que tropt d'exemples à produire tant de l'une que de l'autre Communion" [one would have only too many examples to produce as much from the one Communion as from the other]. ${ }^{70}$

67 Dupraz, Introduction de la Réforme par le "Plus", 171-172; Vuilleumier, Histoire de l'Eglise réformée du Pays de Vaud, vol. IV, 33 ; Henri Germond, "La confrérie réformée d'Echallens pendant le XVIIIe siècle," Revue Historique vaudoise, 44 (1936), pp. 257-275, here at pp. $263^{-265}$.

68 Jaquemard, "Le régime des deux Etats Souverains à Echallens," 281-282; Matzinger-Pfister, Les Coutumiers du Pays de Vaud à l'époque bernoise, 1536-1798, 457.

69 Dupraz, Introduction de la Réforme par le "Plus", 186-188; Jaquemard, "Le régime des deux Etats Souverains à Echallens," 290; Vuilleumier, Histoire de l'Eglise réformée du Pays de Vaud, 4:339-341.

70 ACV, Be 1/2 (bailliage tabs), f. 496r (23 June 1706). 
If the evolution of the confessional climate and the convergence of the preoccupations of both pastors and priests helps to explain the harmony that they found in their collaboration within the Echallens consistory, during the second half of the century of the Enlightenment, their common contribution to ecclesiastic discipline is borne out through the course of the eighteenth century and establishes the exceptional character of this consistory. 